IVANA DOBRIVOJEVIĆ TOMIĆ, PhD, Senior Research Associate

Institute of Contemporary History

Belgrade, Republic of Serbia

ivanadobrivojevic@hotmail.com

originalan naučni rad

UDK: 94:331.109.32(497.1)"1958/1974"

primljeno: 6. oktobar 2018.

338(497.1)"1958/1974"

prihvaćeno: 21. novembar 2018.

https://doi.org/10.29362/ist20veka.2019.1.dob.161-174

\title{
HARBINGERS OF CRISIS. LABOUR STRIKES IN YUGOSLAVIA (1958-1974)*
}

ABSTRACT: The paper discusses the position of workers, the standard of living and economic conditions in socialist Yugoslavia in the 1960s. Special attention has been given to the workers' strikes that frequently occurred in the Yugoslav society since the late 50s. The author analyzes the causes of strikes, their consequences and the reactions that they have caused. The sources from the Archives of Yugoslavia, as well as relevant periodicals and literature were used.

KEYWORDS: workers, strikes, economic policy, standard of living, socialist Yugoslavia

Difficult economic situation and a low standard of living became a reality of everyday life in Yugoslavia in the first postwar decade. An attempt to alter those circumstances in 1955 did not produce desired results. The production stagnated, the national income decreased, the consumption declined, and the factory warehouses accumulated commodities for which there were no buyers. ${ }^{1}$ It was neither possible to stop nor to control the rural - urban migrations once it started. Consequently, a housing shortage in large cities achieved the alarming proportions. Even the President of the SFRY Josip Broz Tito was aware that the promises of a better, socialist future imbuing almost all the speeches of the party officials would no longer suffice. One could hear at the Party meetings and sessions that there was "a large percentage of people working off - hours" and that teachers "were suffering from such a depression" due to low salaries, that it was impossible to "make them care about the problems of upbringing". The events in Hungary and Poland (1956) strengthened Tito's belief that the standard of the population had to be gradually increased. Mean-

\footnotetext{
* This paper is part of the project Serbian Society in the Yugoslav State in the 20th Century: Between Democracy and Dictatorship (no. 177 016) financed by Ministry of Education, Science and Technological Development of Republic of Serbia.

${ }^{1}$ Svetozar Vukmanović Tempo, Revolucija koja teče, IV (Zagreb: Globus, 1982), 188.
} 
while, the announced salaries growth should have followed the increase in labor productivity and the redundancy lay-off. ${ }^{2}$

The year of 1957 was supposed to be a milestone in the economic policy. "The main problem that needed to be solved" as Mijalko Todorović, president of the Federal Executive Council, noted, "was above all raising the living standard of the people who worked primarily as workers and officials". The Second Five Year plan (1957-1961) was set about "removing disproportion" in the economy "having been created by the previous one-sided development". 3 The plan was to reduce the investments into economy, increase the agriculture investments, force the consumer goods production, but also to develop the infrastructure. The living standard had been declared third of the five most important plan goals, ${ }^{4}$ and an increase in goods import was planned in order to meet the demands of the population. ${ }^{5}$ The change in the priorities of economic development, as well as the loans obtained from abroad had a positive influence on the conjuncture. Throughout a few exceptionally successful years, exclusively in the period from 1957 to 1959, the national income was growing at an annual rate of $13.3 \%$, and the industrial production in 1959 was 2.4 times higher in its total volume compared to 1952. A large economic growth, primarily due to the assets from foreign sources, led to a long-announced increase in the standard. The salaries grew faster than productivity, and the consumption of the population in 1959 was $40 \%$ higher than in 1956. According to the official data, the workers nominal wages increased by $52 \%$ in the same period, and the real wages by $39.3 \%$. The increase in the wage range between the skilled and unskilled workers followed the increase in personal income. Purchasing power became additionally higher with loans, ${ }^{6}$ and by the end of the 1950 s, the Yugoslavs, due to higher imports and domestic production, turned to consumption increasingly. Industrial goods became more and more available. Money was spent on clothing, furniture, and household appliances - primarily on refrigerators, stoves, sewing machines and, far less often, on the first television sets. ${ }^{7} \mathrm{~A}$

\footnotetext{
${ }^{2}$ Arhiv Jugoslavije (AJ), fond 507, Centralni komitet Saveza komunista Jugoslavije (CK SKJ), III 8/67, Stenografske beleške sa proširene sednice Izvršnog komiteta CK SKJ održane 6. 11. 1956. u Ljubljani. See also: Ivana Dobrivojević, „Od krize do krize. Životni standard u Jugoslaviji 1955-1965“, Prispevki za novejšo zgodovino, br. 1, (2016), 148-149.

${ }^{3}$ AJ, fond 142, Socijalistički savez radnog naroda Jugoslavije, 142/1-15-41, Stenografske beleške sa sednice Predsedništva saveznog odbora SSRNJ-a održanog 21. 11. 1956.

${ }^{4}$ Branko Horvat, Privredni sistem i ekonomska politika Jugoslavije. Problemi, teorije, ostvarenja, propusti (Beograd: Institut ekonomskih nauka, 1970), 29.

5 AJ, 142/1-15-41, Stenografske beleške sa sednice Predsedništva saveznog odbora SSRNJ-a održanog 21. 11. 1956.

${ }^{6}$ V. Berislav Šefer, Životni standard i privredni razvoj Jugoslavije (Zagreb: Novinsko-izdavački, štamparski i birotehenički zavod, 1965), 101.

${ }^{7}$ I. Dobrivojević, „Od krize do krize“, 151. See also: Предраг Марковић, Београд између Истока и Запада 1948-1968 (Београд: Службени лист, 1996), 313-316; Dragutin Marsenić, Ekonomika Jugoslavije (Beograd: Ekonomika, 1990), 182; Patric Hyder, Bought and Sold. Living and Loosing the Good Life in Socialist Yugoslavia (Ithaca \& London: Cornell University Press, 2011), 33-34.
} 
social stratification gained ground in until then almost monolithic Yugoslav society, so people went to Trieste for shopping, though mostly from Slovenia. ${ }^{8}$

The statistical indicators deftly disguised the old weaknesses of the Yugoslav economy - many investments, often recklessly conceived in order to satisfy the republic and local ambitions, deficit in trade with foreign countries, higher spending, inflation and easy borrowing. It did not take long for this kind of (conjunctural) bubble to burst. Already in 1961 and 1962 the overstretched Yugoslav economy entered a new crisis. The imports liberalization led to the accumulation of goods in warehouses and the poor utilization of facilities, so the National Bank was forced to suspend due payments because of the lack of funds. ${ }^{9}$ The 1961 economic reform, besides reducing the state interfering with the economy, paved the way for a faster social stratification. Since the regulations no longer imposed on companies how much of their profits they should invest and how much they were allowed to spend on salary increases, the board of directors and labour councils became those which decided on further redistribution. The salaries of the highly skilled staff, as well as of the officials, grew faster than the salaries of the workers. Moreover, the amount of income was more and more dependent of the industrial sector in which individuals worked. There were cases when workers in the leather and footwear industry were given a salary increase of $7 \%$ whereas the employees in the oil industry were given a $41 \%$ increase (1961). Although the liberalization of economic conditions came to be a necessity and an inevitability, the decline of unsuccessful companies, the layoffs of redundant workers and the inflation that had grown bigger since $1963 / 1964$ affected mostly the poorest social strata. According to the data from 1963, three thirds of a four-member household budget was spent on groceries and housing, and a family of a less paid worker spent $85 \%$ to $90 \%$ of the income to cover these expenses. The increase in lower salaries was mostly eaten by the prices growth of the groceries. Dissatisfaction grew, and the workers wrote to party leaders emphasizing that it was becoming more and more difficult "to make the ends meet". They mostly complained of salaries, difficult housing situation, low purchasing power and the inaccessibility of consumer goods that one could find in stores. The situation did not differ much throughout the republics, even so the miners from the most industrialized Slovenia were increasingly coming to trade union to seek "help and a loan because they could not live", and threatened to leave the company if they did not receive the required assistance. Dissatisfaction increased prior to the economic reform (1965), and the citizens made supplies of goods saying straightforwardly that "the dinar lost all its value". The reform enabled the inflation suppression, and the standard began to grow again in 1966, with the share of the lowest salaries

\footnotetext{
${ }^{8}$ Мари Жанин Чалић, Историја Југославије (Београд: Clio, 2013), 276. See also: Breda Luthar, „Remembering socialism: On desire, consumption and surveillance”, Journal of Consumer Culture, no. 6, (2006), 229-259.

${ }_{9}^{9}$ AJ, CK SKJ, III/88, Proširena sednica Izvršnog komiteta CK SKJ 14. 3. 1962.
} 
in the total wage bill gradually reducing. The provisions expenditures declined and the balance of savings, unlike in 1964 and 1965 , became positive again. ${ }^{10}$

However, it turned out that the results of the economic reform remained slim. The conjucture as seen in the late 1950s was obviously impossible to repeat. The economy production increased only by $18 \%$ in the period from 1964 to 1968 , considerably lower than $54 \%$ recorded in the previous four-year period. Moreover, the employment had also fallen for the first time since 1952. The pressure of the entire generations of young people looking for a job dropped with a temporary employment in the countries of the Western Europe. The emigration only managed to postpone but not stop the upcoming crisis. The authorities did not have a clue how to overcome the structural problems, so the Yugoslav economy was lagging even more behind the developed countries of the Western Europe. ${ }^{11}$ Moreover, the suspension of the administration methods to manage the economy brought back new challenges. Many companies fell into endless economic hardships. The production increased regardless of the demand, the goods were stored in warehouses, the losses were rising, and the salaries were late. Although the regulations stipulated that all the companies unable to cover the losses had to provide a recovery program calling for the conditions of further profitable operations, most of them avoided this obligation. Fearing the social implications, the authorities followed the path of less resistance, somehow managing liquidity through loans, or by way of transferring funds from well-performing businesses. ${ }^{12}$

By liberalizing consumer loans the authorities sparked the revival of turnover and the reduction of consumer goods in the stockpiles from the local production. ${ }^{13}$ Although a part of the Yugoslavs was not satisfied with the living standard, the salaries growth stood in disproportion to the potentials of the Yugoslav economy. A spiral had been created in which the salary growth led to a rise in production and the prices as well. The economy revival was short-lived. ${ }^{14}$ The year of 1969 brought a new price increase, ${ }^{15}$ followed by a new slowdown in the economic growth, a decline in the employment and the living standard in the late 1970s and in early $1971 .^{16}$ The prices continued to rise making the costs of living for the first eight months in 1973 higher by $24 \%$ than in the same period a year

${ }^{10}$ I. Dobrivojević, „Od krize do krize“, 154-158. See also: Ивана Добривојевић, „Југословени о сиромаштву. Трагом једног документа“, Токови историје, бр. 2, (2016), 199-214; Slobodan Selenić, „Pogledi Josipa Broza na neke probleme jugoslovenskog društva šezdesetih godina 20. veka“, u: Tito: Viđenja i tumačenja, priredili Olga Manojlović Pintar, Mile Bjelajac, Radmila Radić (Beograd: INIS, 2011), 332-333.

${ }^{11}$ Dušan Bilandžić, Historija SFRJ. Glavni procesi 1918-1985 (Zagreb: Školska knjiga Zagreb, 1985), 314-319.

12 AJ, fond 837, Kabinet Predsednika Republike (KPR), II-3-c-2/81, Stabilizacija i intenzifikacija privređivanja, maj 1971.

13 AJ, 837, KPR II-5-c-2/206, Privredna kretanja u 1968. i razvojne mogućnosti i elementi ekonomske politike u 1969, 9. 10. 1968.

${ }^{14}$ AJ, 837, KPR, II-3-c-2/81, Stabilizacija i intenzifikacija privređivanja, maj 1971.

${ }^{15}$ AJ, 837, KPR, II-3-c-2/60, Predsedništvo Veća Saveza sindikata Jugoslavije o privrednim kretanjima i ostvarivanju ciljeva i mira ekonomske politike, 16. 6. 1969. See also: B. Horvat, $n$. d., 58.

${ }^{16}$ AJ, 837, KPR, II-3-c-2/81, Stabilizacija i intenzifikacija privređivanja, maj 1971. 
ago, whereas the actual salaries were less by $6 \%$. The losses of the companies were growing rapidly, and as many as 256300 workers received reduced salaries. ${ }^{17}$ General policy of frugality was declared and the companies were advised (demagogically) to reduce unnecessary costs related to the upcoming New Year holidays at the end of 1972, and redirect the assets to solidarity funds in order to build housing for workers and help sick and financially vulnerable employees. ${ }^{18}$

The social stratification was also gaining momentum - about $40 \%$ of workers earned less than 600 dinars in 1968, while high-ranking officials and intellectuals effected relatively high salaries in a socialist background. The society was becoming more and more consumer like, the variety of good was increasing, and bit by bit almost every Yugoslav dreamed of possessing technical devices, and later on cars, which also became a kind of a status symbol. The range between the lowest and highest earnings reaching the $1: 10$ ratio testified of a somehow social overturning to an almost monolithic socialist society. ${ }^{19}$ Due to the large salaries range, the level of personal standard of employees of the same or similar qualifications also differed, depending on which branch, group or company they worked at. The differences thus created became an incentive for "various reactions and dissatisfaction", which was enhanced by the faster growth of salaries in the non - production sectors. ${ }^{20}$ Even the official party reports could not conceal a difficult financial situation of the majority of the workers in production, emphasizing that "a relatively large number of employees, especially in labor-intensive industries, had minimum or low personal incomes." 21 The housing crisis had also been linked to the growing social disparities, since companies generally favored experts in the apartments distribution. ${ }^{22}$ In the situation created by the economic crisis, unemployment and job insecurity mostly felt by the workers in production, a standard growth of one category of the population provoked a growing dissatisfaction among the poorest. The situation was additionally fueled by the newspapers encouraging the consumption of various goods through commercials, but also writing about embezzlements and unreasonable costs in companies. ${ }^{23}$ Easily given promises of a classless society and social equality, which imbued the speeches of senior party leaders for years, returned both as an economic and a political boomerang. The betrayed (unrealistic) expectations of the parts of the population created an atmosphere in which strikes, at that time euphemistically referred to as "work cessation" and "resolving conflict situations", became one of the main means by which workers dissatisfied with their financial situation made pressure on the authorities.

\footnotetext{
${ }^{17}$ AJ, 837, KPR, II-3-2/108, Različite ocene ekonomske situacije.

${ }^{18}$ AJ, 837, KPR, II-3-c-2/96, Informacija sa sednice Predsedništva veća SSJ o štednji, izgradnji stanova za radnike, izmenama u radnom zakonodavstvu, poreskom sistemu i penzijskoinvalidskom osiguranju, 7. 12. 1972.

${ }^{19}$ D. Bilandžić, $n . d ., 340$.

${ }^{20}$ AJ, 507, CK KJ, IV, k 3/6 (1968), Neka pitanja razvoja životnog standarda.

21 AJ, 837, KPR, II-3-c-2/60, Predsedništvo Veća Saveza sindikata Jugoslavije o privrednim kretanjima i ostvarivanju ciljeva mira i ekonomske politike, 16. 6. 1969.

${ }^{22}$ Sreten Vujović, Ljudi i gradovi (Budva: Mediteran, 1990), 50, 52-55.

${ }^{23}$ AJ, 837, KPR, II-3-a-1/16, Proširena sednica Izvršnog biroa CK SKJ, Beograd, 6. 2. 1958.
} 
The first strike in the socialist Yugoslavia broke out in the Trbovlje mine in January $1958 .{ }^{24}$ Although the party leadership was aware of the possible political implications of the unsatisfactory living standards ${ }^{25}$ the economic conjucture that occurred in 1957 "caught Yugoslav leader off guard", as Svetozar Vukmanović Tempo testified. ${ }^{26}$ The reason for a work cessation was a difficult financial situation of the mine caused by the increase in electricity costs and high costs of coal production the price of which was set high by the federal regulations. Although the leadership of the mine, the trade union branch and the factory committee of the League of Communists sought help from local, republic and federal authorities for days, it turned out that the negotiations could not solve the accumulated problems. Therefore, in the middle of January in 1958, a peaceful and a non-violent two and a half day strike broke out. ${ }^{27}$ The strike was primarily directed at the federal bodies that, as Trbovlje believed, showed insufficient understanding for the miners. The eruption of anger was caused by the fact that whereas all the employees in Slovenia received an extra salary on the Day of the Republic, only the mine in Trbovlje had no funds to pay the salary. All the employees (around 4000 people), including the members of the Labour Council and the Board of Directors, took part in the strike. Although the press, radio and television did not report a single word about it (which remained a practice for a following few years), the information about this event spread throughout the country. ${ }^{28}$

A peaceful and a non-violent protest in the mine circle could have easily caused major problems. Namely, Tempo testified that the couriers carrying letters in which the strike committee invited other companies in Slovenia to join them were caught. The fact that Edvard Kardelj, Aleksandar Ranković and Mijalko Todorović immediately left for Slovenia spoke clearly of the fear at the party summit caused by the strike. ${ }^{29}$ Although not only party organization of the mine, but also of municipality and even county were disbanded as a punishment, with the accusations of "infiltrating the enemy", all the demands of the workers, especially those related to the price of enamel and technical protection were accepted. ${ }^{30}$

Tito realized that because of the low standard, the strike in Trbovlje was "one of many that might happen to us". Therefore, at an expanded session of the Executive Bureau of the CK SKJ held in February 1958, he criticized the "waste" causing "the employee dissatisfaction", "travelling abroad without needs", "unnec-

\footnotetext{
${ }^{24}$ Predrag Marković writes that he heard in the conversation with general Šijan that strikes were organized in Belgrade in 1955: Предраг Марковић, „Раднички штрајкови у социјалистичком и транзиционом друштву Југославије и Србије“, Токови историје, бр. 1, (2014), 53.

${ }^{25}$ AJ, CK SKJ, III 8/67, Stenografske beleške sa proširene sednice Izvršnog komiteta CK SKJ održane 6. 11. 1956. u Ljubljani.

${ }^{26}$ S. Vukmanović, Revolucija koja teče, IV, 226.

${ }^{27}$ Nebojša Popov, „Štrajkovi u savremenom jugoslovenskom društvu,“ Sociologija, br. 4, (1969). Published on http://zsf.rs/strajkovi-u-savremenom-jugoslovenskom-drustvu/\#_ftn15.

28 „Штрајк и самоуправљање“, Борба, 27. 9. 1969.

${ }^{29}$ S. Vukmanović, Revolucija koja teče, IV, 226.

${ }^{30}$ П. Марковић, „Раднички штрајкови у социјалистичком и транзиционом друштву Југославије и Србије“, 53; „Штрајк и самоуправљање“, Борба, 27. 9. 1969.
} 
essary car buying" and the use of it for personal purposes, a very rapid increase in the wage range, "which gave workers an excuse" to say that the bourgeoisie was being created with us again", although all of them, as the workers in Trbovlje said, "had the same stomachs". However, Josip Broz blamed the local party organization and trade unions members for the strike who, by failing to understand "their role" and "their tasks", were on the side of the strikers instead of "taking care of the community as a whole", also speaking about "the harm that could be brought about by one such phenomenon" which remained "a stain on our entire system". 31

The prompt acceptance of the demands of the strikers in Trbovlje created a precedent that worked successfully in the years to come. The work suspension, especially in the second half of the 1960s, also accompanied with a media coverage, immediately attracted the attention of all society levels - municipal, state, republic and federal. The demands of the strikers were accepted in the shortest period possible. The problems that were being pointed out as pending for several months, were as a rule immediately resolved. Even company directors themselves used to send dissatisfied labour delegations coming to them to higher authority levels. Director of the Yugoslav Railways Directorate in Ljubljana advised the workers: "Stand up for your rights with all the forums". "Provide me with all the necessary documentation and I will fix that matter with Krajger and Leskošek. If it is not enough, we will go to Kardelj. I will not be able to go with you because I am a member of the Council of Producers". ${ }^{32}$ The party leaders were also aware of the prevalence of this practice, and a report summarized it once that "sometimes a work cession suited technocratic and bureaucratic structures of the working organizations" thus enabling them to exert pressure on higher authority levels "even when bad operating results were the matter of their incapacity". 33

Despite the prevalence of strikes during the 1960s and 1970s, the federal and republic constitutions, laws and other legal documents contained no paragraphs regulating this practice. ${ }^{34}$ Assuming that there should be no strikes in socialism, the party leaders thought that frequent work suspension "had their roots in the deformations of the self-management system", "the underdevelopment of truly democratic relations", "the distribution according to the work results" and "the absence of self-management mechanisms for resolving conflict situations". ${ }^{35}$ Although the Yugoslav authorities had a tolerant attitude towards the strikers incomparable with the practice in other socialist countries, UDBA representatives used to be present at the meetings with workers in the companies affected by a strike, especially at the end of the $1950 \mathrm{~s},{ }^{36}$ which was probably regarded with a certain amount of trepida-

${ }^{31}$ AJ, 837, KPR, II-3-a-1/16, Proširena sednica Izvršnog biroa CK SKJ, Beograd, 6. 2. 1958.

${ }^{32}$ AJ, fond 117, Savez sindikata Jugoslavije, 117-73-170, Nezadovoljstvo radnika i službenika i neke druge pojave u Jugoslovenskim železnicama. - Izveštaj je rezultat provere koju su izvršila odeljenja saveznog i republičkih državnih sekretarijata za unutrašnje poslove.

${ }^{33}$ AJ, 837, KPR, II-3- c-2/104, Informacija o obustavama rada u Jugoslaviji od 1. januara do 1. juna 1973.

${ }^{34}$ Neca Jovanov, Radnički štrajkovi u SFRJ od 1958. do 1969 (Beograd: Zapis, 1979), 35-36.

35 AJ, 837, KPR, II-3-c/64, Konfliktne situacije u radnim organizacijama i način njihovog rešavanja, 15. 9. 1969.

${ }^{36}$ AJ, 117-73-170, Informacija broj 5. Štrajk 77 rudara u rudniku „Krmelj““, 3. 11. 1958. 
tion. The perception of a strike as "the result of a hostile campaign against socialism", which was to be dealt with by the state authorities was abandoned after some time, but still "encouragement of bullying, demonstration and provocations of riots in the streets and prevention of a dialogue" was regarded as anti-socialist activism. ${ }^{37}$ Nevertheless, the League of Communist had a somewhat ambivalent attitude towards increasingly frequent strikes, since they were neither permitted nor prohibited. It was thought that the legalization of a strike would be "a turning back to selfmanagement" and the acceptance of state socialism, while their administrative ban would signify a negation of the conflict. Even though the work suspensions were regarded as "degrading for the self-management" yielding solutions outside financial opportunities "at the expense of the majority,",38 the highest party and state leaders had a tolerant attitude towards strikes. Predrag Marković stated that during 1965 and 1966 Miloš Minić, Veljko Vlahović and Vladimir Bakarić acknowledged the fact that workers "fought against bureaucratic defamations" in that way. ${ }^{39}$ However, the initiative of the Federal Council's Economy Committee to open a debate on strikes in January 1966 was not met. The Federal Labor Secretariat held a view that supervising work suspension was not legally binding for them, since it was a job of the trade unions. ${ }^{40}$

By the end of 1969, the views of the League of Communist were crystallized in relation to labour strikes. The party held a view that its members together with the members of the Trade Unions League "had to oppose vigorously the pressures of every kind to solve problems and difficulties outside the self-governing structures," since the work cessions "undermined the selfgoverning system", "eliminated a constructive dialogue" and inhibited "selfmanagement and economic movement of a society". 41

The dissatisfaction with the living and working conditions in the period of administrative management of the economy, was expressed primarily by leaving a company, as evidenced by the large fluctuation of the labor force. ${ }^{42}$ The liberalization of economic situation, as well as the rising unemployment rate, opened new ways for those who were struggling to improve their financial status. The dissatisfied workers could go abroad to work or try to reach higher positions within the company, and get those rights they believed belonged to them. Nevertheless, work cessions were only an echo of dissatisfaction, which was more openly expressed inside the companies. There were cases of indifferent attitude towards work, and one could hear during the talks: "We work as

37 AJ, 837, KPR II-3-c/64, Konfliktne situacije u radnim organizacijama i način njihovog rešavanja, 15. 9. 1969.

${ }^{38}$ AJ, 837, KPR II-3/64, Informacija o nekim mišljenjima u vezi sa obustavama rada (7. 10. 1969).

${ }^{39}$ П. Марковић, „Раднички штрајкови у социјалистичком и транзиционом друштву Југославије и Србије“, 55-56.

${ }^{40}$ N. Jovanov, Radnički štrajkovi u SFRJ od 1958. do 1969, 36.

${ }^{41}$ AJ, 837, KPR, II-3-c-2/64, Predlog zaključaka o konfliktnim situacijama i načinu njihovog razrešavanja, 18. 9. 1969. Zaključci su usvojeni 26. 6. 1970.

42 Ivana Dobrivojević, Selo i grad. Transformacija agrarnog društva Srbije 1945-1955 (Beograd: Institut za savremenu istoriju, 2013), 224-225. 
much as they pay us". The (low) salaries were openly discussed during the working hours, ${ }^{43}$ as well as the fact that "workers could not work hungry", that they "did not care" and that "there was nothing of what Tito spoke in Spilt". 44 Although the official reports recognized financial reasons and the abolition of acquired labor rights as the main cause of strikes, the leaders and members of the League of Communists in the company were actually blamed for the erupted dissatisfaction of workers. It was pointed out that their inactivity, "ultimate political immaturity", "non-alertness", and ideological - political and organizational inability "to cope with the problems and contradictions of life" disabled the prevention or at least management of the strikes. ${ }^{45}$

The workers who suspended their work were not against socialism as a system. ${ }^{46}$ They stood up against what was, in their opinion, its own negation. The slogans against the growing social differences that were shouted within Yugoslav factories served as a testimony to it. "Stop explotation"; "Comrade Tito said that the man was the most important"; "We want socialist rewards"; "Let us go to Holland and Germany"; "How can we be friends with them" (thinking of managers); "We are hungry; our children are hungry"; "We don't want to have a tie and a limousine, we want bread" were some of the slogans shouted by the strikers. The number of strikes had steadily grown, so around 760 work cessions were registered throughout the country in the period form 1958 to the first half of 1964 . However, the number of strikes was certainly considerably higher, since in Slovenia (until 1960), Bosnia and Herzegovina and Serbia (until 1963) there was no systematic monitoring of this type of labor dissatisfaction. ${ }^{47}$ The Federal Labour Council and the Trade-Union Council sent a questionnaire to all municipal assemblies and union councils with a request to provide information on strikes that broke out in the period from January 1958 to September 1969 in order to get approximately reliable information about the number of the work cessions. Out of the total number of 478 municipalities there were 372 that responded. Although the results of the inquiry were incomplete and flawed, the obtained data indicated a certain concentration of strikes in the major cities, especially in the industrial centers. According to that survey, 302 companies were on a strike, some of which several times, mostly from the industry and mining sectors located in 180 municipalities. ${ }^{48}$ Despite seeing the need to collect and process data on the workers strikes, the precise statistics on the actual number of work cessions did not exist in the early 1970 s. Namely, the

\footnotetext{
${ }^{43}$ AJ, 117-73-170, Nezadovoljstvo radnika i službenika i neke druge pojave u Jugoslovenskim železnicama. -Izveštaj je rezultat provera koje su izvršila odeljenja saveznog i republičkih državnih sekretarijata za unutrašnje poslove.

44 AJ, 837, KPR, II-3-a-2/52, Aktuelne političke informacije odeljenja za dokumentaciju i informacije CK SKJ i CO SSRNJ 3-29. 2. 1964.

45 AJ, 837, KPR, II-3-c/64, Konfliktne situacije u radnim organizacijama i način njihovog rešavanja, 15. 9. 1969.

${ }^{46}$ AJ, 837, KPR, II-3-c-2/64, Informacije sa sednice Predsedništva Veća SSJ održane 7. 10. 1969.

${ }^{47}$ AJ, 837, KPR, II-3-c-2/28, Informacija o obustavama rada za period 1958 - prvo polugođe 1964.

${ }^{48}$ AJ, 837, KPR, II-3-c-2 / 64, Neka kvantitativna obeležja obustava rada.
} 
companies and local authorities "sometimes hid these phenomena", and the registered number of strikes did not reflect "the real economic and social problems and the actual mood of the workers." 49

The strikers were almost as a rule blue collar workers and it was usually only a part of the team that suspended work. Thanks to a quick response of the municipal, district and republic authorities that accepted labor demands, the strikes were short. They usually lasted several hours. The number of the participants in a strike was growing year in year out, and the cessions used to be periodically repeated in the same companies. "Varteks" from Varaždin, cement factory "Kromačno" from Pula, Uljanik shipyard, PIK Vukovar, Makedonka from Štip were only some of the companies in which more and more workers suspended their work in each subsequent strike. ${ }^{50}$ The strikes gained on intensity and determination in time, strike committees were formed, and the workers, especially from the mid $1960 \mathrm{~s}$, increasingly went outside the company to demonstrate, trying to give a pervasive social problem a wider political character. ${ }^{51}$ The workers of Tomos shouted in the streets of Koper: "We want our money", while the employees in Niš Express demonstrated in the city shouting "minimum wages for life". ${ }^{52}$ The authorities, which endeavored to end any strike as soon as possible, were especially stunned by street demonstrations, believing that they "expanded allowing infiltration of the enemy elements". The susceptibility of the state authorities to accept the demands of the strikers could not completely prevent the phenomenon of a definite job abandonment. There were similar cases recorded in Serbia, Croatia and Slovenia. 120 workers thinking they were deprived of a portion of a monthly earnings left "Sisak Ironworks", while 1000 workers left the factory "Rade Končar" because of low salaries, among which a larger number of skilled and highly skilled workers. ${ }^{53}$

Even though the strikes were primarily organized in those sectors of economy characterized with harder operating conditions, the protest cessions also took place in those companies with a relatively stable financial standing. The dissatisfaction in the production was also transferred to the public sector, with strikes in primary and secondary schools, judiciary and health care. ${ }^{54}$ The workers of all qualifications took part in work cessasions, as well as the members of the League of Communists and the members of workers councils. Reduced and irregular salaries, increased norms, reduced holidays and regresses for holidays, restricting conditions for a sick leave, abolishing or reducing compensation for commuting and food, laying off workers in production as technol-

49 AJ, 837, KPR, II-3-c-2/104, Informacija o obustavama rada u Jugoslaviji od 1. januara do 1. juna 1973. Iz Veća Saveza sindikata Jugoslavije (6. 6. 1973). On number of strikes see also: Слободан Селинић, „Посета Јосипа Броза Банату 25. октобра 1969“, Архив, бр. 1-2, (2014), 177.

${ }^{50} \mathrm{AJ}, 837, \mathrm{KPR}, \mathrm{II}-3-\mathrm{c}-2 / 28$, Informacija o obustavama rada za period 1958 - prvo polugođe 1964.

51 „Штрајк и самоуправљање“, Борба, 27. 9. 1969.

52 AJ, 837, KPR, II-3-c-2/64, Štampa o obustavama rada u Jugoslaviji.

${ }_{53}$ AJ, 837, KPR, II-3-c-2/28, Informacija o obustavama rada za period 1958 - prvo polugođe 1964.

54 „Две поуке из Словеније“, Борба, 25. 5. 1968; „Пред затвореним амбулантама“; Политика, 5. 7. 1968. 
ogy redundancies, and the belief that worker advice served only as a decoration and the reason that workers did not take part in making important decisions in companies were some of the main causes of strikes. ${ }^{55}$ Having got used to the administrative management of the economy, the workers themselves were unrealistic in their demands, demanding that the entire profit of the company be divided into salaries or that the wages be divided according to the principle of equilibrium. ${ }^{56}$ There were also quite ingenuous demands. The miners in Zagorje ob Sava, who suspended work only two days after the strike in Trbovlje was over, demanded, among other things, that they were guaranteed the payment of a thirteenth salary every year, and a bonus of 50\% in January, and $100 \%$ in May regardless of the economic results of their mine, but also to dismiss all those who did not cooperate with the strikers openly. ${ }^{57}$ The conflict between increasingly market-oriented directors and the workers who stood up against social differences and the layoffs culminated in 1967 when Svetozar Vukmanović Tempo was dismissed as the President of the Trade Unions, since he publicly stood up against market-oriented management of companies. ${ }^{58}$

Eleven years after the strike in Trbovlje the authorities were surprised and deeply upset by the strike in Rijeka's port. The actual cause of the strike was the reduction in wages, overtime compensation and sick leaves caused by the heavy losses of the port the manufacturing workers had been deeply affected by. Although the restrictive measures had been formally approved of at the Workers' council, there were indications that two port workers voting for the unpopular measures were financially rewarded for that "service." was due to the workers being poorly informed of the restrictive measures taken at the labour council or the dissatisfaction with them, but a revolt broke out on 2 June 1969. The 800 workers of the first and third shifts went on strike, followed by another 4500 people who subsequently suspended work in the continuation of two days. A part of the workers gathered around an administrative building, when one group physically attacked the general and commercial director causing them physical harm, while the other group expelled all administrative staff from the office. The head of the bookkeeping, as well as the head of joint services, the analyst, the director of the economy sector and the president of the trade union branch were attacked then. ${ }^{60}$ The authorities were anxious that stu-

${ }^{55}$ AJ, 837, KPR, II-3-c/64, Konfliktne situacije u radnim organizacijama i način njihovog rešavanja, 15. 9. 1969; Vladimir Azrenšek, „Otuđenje i štrajk“, Revija za sociologiju, бp. 2-3, (1976), 6-7.

${ }^{56} \mathrm{AJ}, 837$, KPR, II-3-c-2/28, Informacija o obustavama rada za period 1958 - prvo polugođe 1964.

57 „Штрајк и самоуправљање“, Борба, 27. 9. 1969.

58 Susan L. Woodward, Socialist Unemployment. The Political Economy of Yugoslavia 19451990 (Princeton: Princeton University Press, 1995), 273.

${ }^{59}$ Goldie Shabad, „Strikes in Yugoslavia: Implications for Industrial Democracy“, British Journal of Political Science, no. 3, (1980), 301. About the dissatisfaction with the decisions of workers' council that were among the causes of strike in Uljanik in 1967: Igor Stanić, „Jedan od najtežih dana u Uljaniku! - štrajk u brodogradilištu Uljanik 1967. godine", Problemi sjevernog Jadrana, br. 15, (2016), 73-95.

${ }^{60} \mathrm{AJ}, 837$, KPR, II-3-c-2/64, Informacija Saveznog sekretarijata za unutrašnje poslove o narušavanju javnog reda i mira prilikom obustava rada u nekim radnim organizacijama, 23. 6. 1969. 
dents, as well as employees in other companies which were in a even more difficult economic situation would come to support to the workers, especially given the upcoming anniversary of the upcoming students unrest. The police came out into the streets, yet the plan was not to take any special measures except to block that part of the port occupied by the strikers. ${ }^{61}$ According to the official reports, a number of workers were throwing various staff at the police, causing the police to use force and police sticks, "thus making the majority retreat". 62 This brought about the reaction of the highest authority levels again - Vice President of the Republic Executive Council Dušan Dragosavac and Vice President of the Republic Board of Trade Unions travelled to Rijeka immediately. ${ }^{63}$ An agreement was reached with strikers to abolish the new tariff rulebook and reintroduce the old one. The workers started leaving for their homes. The criminal charges were filed against 20 people, the investigations were opened against 14, and 6 people were held in detention. ${ }^{64}$ Even though the strike had been quieted down, the authorities were afraid of a new strike breaking out since the workers identified as strike leaders were arrested, As many as 130 police officers from Zagreb, Karlovac and Pula were subsequently sent to Rijeka as a back up. ${ }^{65}$

However, the frequency and prevalence of strikes did not prompt the authorities to introduce a right to a strike into the new Constitution (1974). Since Yugoslavia was a signatory of the International Covenant on Economic, Social and Cultural Rights, which guaranteed the right to suspend work in accordance with the laws of each country, the Federal Legal Council asked the Council of the Union of Trade Unions to send their representative to a meeting in July 1973 to discuss the inclusion of a right to a strike into the draft Constitution. Dragoslav Mišić, the Secretary of the Council of Trade Unions, justified his attitude about a strike by saying that it should not become a constitutional right, given the fact that the workers as self-governors decided directly on all the essential issues in the country. Tellingly, before starting the aforementioned presentation, Mišić distanced himself from it by saying: "I have to distance myself at the very beginning and what I am going to say is not the opinion of the Presidency of the Council of the Trade Unions of Yugoslavia, but these are the opinions and attitudes of a narrow circle of the comrades in the Council Secretariat of the Trade Unions of Yugoslavia". 66

A deeper global economic and political crisis, especially at the beginning of the 1980s, increased the number of workers fighting to achieve a better economic situation through strikes. The number of participants in work suspensions, as well as their length was growing steadily. The number of strikers in

\footnotetext{
${ }^{61}$ AJ, 837, KPR, II-4-a/70, Informacija o događajima u Riječkoj luci.

${ }^{62}$ AJ, 837, KPR, II-3-c-2/64, Informacija Saveznog sekretarijata za unutrašnje poslove o narušavanju javnog reda i mira prilikom obustava rada u nekim radnim organizacijama, 23. 6. 1969.

${ }^{63} \mathrm{AJ}, 837$, KPR, II-4-a/70, Informacija o događajima u Riječkoj luci.

${ }^{64}$ AJ, 837, KPR, II-3-c-2/64, Informacija Saveznog sekretarijata za unutrašnje poslove o narušavanju javnog reda i mira prilikom obustava rada u nekim radnim organizacijama, 23. 6. 1969.

${ }^{65}$ AJ, 837, KPR, II-4-a/70, Obustava rada u luci Ploče, 5. 6. 1969.

${ }^{66}$ N. Jovanov, Radnički štrajkovi u SFRJ od 1958. do 1969, 39-40.
} 
1988 was 28.5 times higher than in $1980 .{ }^{67}$ However, the increasing liberalization of society and institutional deterioration which was slowly affecting entire society prompted the government to lose interest in solving the strikes immediately. The increase of strikers and strikes therefore did not contribute to their greater efficiency, since the demands of strikers during the 1960s and the first half of the 1970s were being promptly accepted, while in the 1980s only demands of those workers who were important for the system were met. ${ }^{68}$

\section{REFERENCES}

- Azrenšek, Vladimir. „Otuđenje i štrajk“. Revija za sociologiju, br. 2-3, (1976), 3-16.

- Bilandžić, Dušan. Historija SFRJ. Glavni procesi 1918-85. Zagreb: Školska knjiga Zagreb, 1985.

- Čalić, Mari Žanin. Istorija Jugoslavije u 20. veku. Beograd: Clio, 2013.

- Dobrivojević, Ivana. „Jugosloveni o siromaštvu. Tragom jednog dokumenta“. Tokovi istorije, br. 2, (2016), 199-214.

- Dobrivojević, Ivana. „Od krize do krize. Životni standard u Jugoslaviji 19551965“. Prispevki za novejšo zgodovino, br. 1 (2016), 145-160.

- Dobrivojević, Ivana. Selo i grad. Transformacija agrarnog društva Srbije 1945-1955. Beograd: Institut za savremenu istoriju, 2013.

- Horvat, Branko. Privredni sistem i ekonomska politika Jugoslavije. Problemi, teorije, ostvarenja, propusti. Beograd: Institut ekonomskih nauka, 1970.

- Hyder, Patric. Bought and Sold. Living and Loosing the Good Life in Socialist Yugoslavia. Ithaca \& London: Cornell University Press, 2011.

- Luthar, Breda. „Remembering socialism: On desire, consumption and surveillance." Journal of Consumer Culture, no. 6, (2006), 229-259.

- Marković, Predrag. „Radnički štrajkovi u socijalističkom i tranzicionom društvu Jugoslavije i Srbije“. Tokovi istorije, br. 1, (2014), 53-74.

- Marković, J. Predrag. Beograd između Istoka i Zapada 1945-1965. Beograd: Službeni list SRJ, 1996.

- Marsenić, Dragutin. Ekonomika Jugoslavije. Beograd: Ekonomika, 1990.

- Neca, Jovanov. Radnički štrajkovi u SFRJ od 1958. do 1969. Beograd: Zapis, 1979.

- Novaković, Nada. Propadanje radničke klase. Materijalni i društveni položaj radničke klase Jugoslavije od 1960. do 1990. godine. Beograd: Rad, 2007.

- Selenić, Slobodan. „Poseta Josipa Broza Banatu, 25. oktobra 1969“. Arhiv, br. 1-2, (2014), 169-181.

- Selenić, Slobodan. „Pogledi Josipa Broza na neke probleme jugoslovenskog društva šezdesetih godina 20. veka“. U: Tito: Viđenja i tumačenja. Urednici Olga Manojlović Pintar, Mile Bjelajac, Radmila Radić, 329-346. Beograd: INIS, 2011.

${ }^{67}$ П. Марковић, „Раднички штрајкови у социјалистичком и транзиционом друштву Југославије и Србије“, 59.

${ }^{68}$ Nada G. Novaković, Propadanje radničke klase. Materijalni i društveni položaj radničke klase Jugoslavije od 1960. do 1990. godine (Beograd: Rad, 2007), 126. 
- Shabad, Goldie. „Strikes in Yugoslavia: Implications for Industrial Democracy“. British Journal of Political Science, no. 3, (1980), 293-315.

- Stanić, Igor. „Jedan od najtežih dana u Uljaniku! - štrajk u brodogradilištu Uljanik 1967. godine“. Problemi sjevernog Jadrana, br. 15, (2016), 73-95.

- Šefer, Berislav. Životni standard i privredni razvoj Jugoslavije. Zagreb: Novinsko-izdavački, štamparski i birotehnički zavod Zagreb, 1965.

- Vujović, Sreten. Ljudi i gradovi. Budva: Mediteran, 1990.

- Vukmanović Tempo, Svetozar. Revolucija koja teče, tom IV. Zagreb: Globus, 1982.

- Woodward, Susan. Socialist Unemployment. The Political Economy of Yugoslavia 1945-1990. Princeton: Princeton University Press, 1995.

IVANA DOBRIVOJEVIĆ TOMIĆ, PhD, Senior Research Associate Institute of Contemporary History

Belgrade, Republic of Serbia

ivanadobrivojevic@hotmail.com

\section{HARBINGERS OF CRISIS. \\ LABOUR STRIKES IN YUGOSLAVIA (1958-1974)}

\section{Summary}

The relative liberalization of the Yugoslav socialist economy and its limited transition to market economy have led to an increase in social differences. A sizable segment of manufacturing workers, employed in non-profitable enterprises, lived in difficult material conditions. Unrealistic expectations and promises of a bright socialist future have created an atmosphere in which, starting in 1958, the worker strikes became one of the main means of pressure on political elite. Blue collar workers represented the majority of strikers. Some of the main causes of strikes were: reduced and irregular salaries, increased norms, reduced holidays and holiday compensation, restricting conditions for a sick leave, abolishing or reducing compensation for commuting and food, laying off workers in production as technology redundancies. Moreover, the belief that Workers' Councils served only as a decoration and the reason that workers did not take part in making important decisions in companies significantly contributed to worker's dissatisfaction. Due to a quick response of the municipal, district and republic authorities that mostly accepted labor demands, the strikes were short. The number of strikers was steadily rising. However, the rise of workers' protests did not contribute to their greater efficiency, since the demands of strikers during the 1960s and the first half of the 1970s were being promptly accepted, while in the 1980s only demands of those workers vital for the system were met.

KEYWORDS: workers, strikes, economic policy, standard of living, socialist Yugoslavia 